\title{
HPC 環境において MPI を用い FUNDAMENTAL RESEARCH ON た並列演算処理の建築分野への APPLICABILITY OF PARALLEL 適用性に関する基礎的研究 PROCESSING THAT USES MPI ON HPC SYSTEM
}

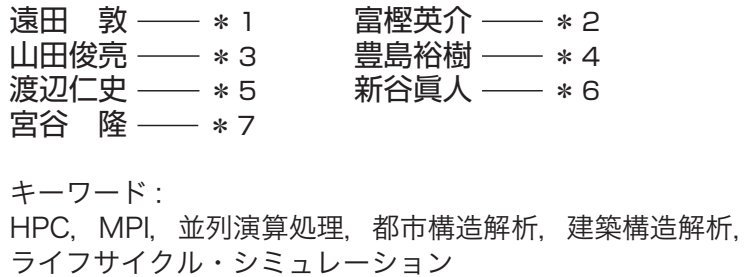

Keywords:

High performance computing, Message passing interface, Parallel processing, Analysis of urban structure, Analysis of architectural structure, Lifecycle simulation

Atsushi ENTA $-* 1$
Shunsuke YAMADA - $* 3$
Hitoshi WATANABE - $* 5$
Takashi MIYATANI - $* 7$

Eisuke TOGASHI $-* 2$
Yuki TOYOSHIMA $-* 4$
Masato ARAYA $* 6$

We did the three analysises used the parallel processing on HPC system. One is an analysis of the urban structure in the field of urban and architectural planning. Another one is a dynamical simulation of air conditioning facilities in the field of environmental engineering. The other is an analysis of the behavior of the masonry construction in the field of construction engineering.

We clarified the availability of the HPC system in an architectural field because of the improvement of the computational speed and the expansion of an analytical scale.

\section{1. 研究背景}

近年では、ひとつの CPU に複数の CPU コアを搭載したマルチ コア・プロセッサが一般化しつつあり、市販のデスクトップ PC や ノート PC でも複数のコアを用いた並列演算処理が可能となってき ている。市販の PC を複数台連結させて構成したクラスタ型のハー ドウェア構成においても、並列処理を制御するためのソフトウェア がリリースされており、これを活用することで小〜中規模な High Performance Computing (以降、HPC) 環境を構築することができる。

大型の研究プロジェクトでは、専用のスーパーコンピュータを 用いて並列処理の専門家らが大規模な計算に取り組んでいる。HPC 環境で並列処理を実施することのメリットは、並列処理を専門とし ない者でも、手近にある機器を連結して構成したコンピュータ・ク ラスタにおいて、簡易かつ安価なコストで並列処理による計算の高 速化を実現することができるということであろう。

建築分野においても、建築構造解析や環境シミュレーション、歩 行者シミュレーションなどといったテーマにおいて、高速かつ大規 模な計算機が求められる場面がある。しかしながら、そのような計 算環境の手配には高額な費用が必要となるだけでなく、機器を管理 するための場所や設備の確保、設備機器の陳腐化などが問題になる ことで、結局導入には至らないということがある。

そこで本報では、一般向けのPC を連結して構築できるコンピュー タ・クラスタに対して並列処理用のソフトウェアを導入し、計算規 模や速度がどの程度向上するか検証することで、建築分野全般にお ける HPC 環境の利用可能性について検討を行う。

\section{2. 研究目的}

計画・構造・環境の三分野それぞれの研究において、コンピュー
タ・クラスタを用いた大規模な並列演算処理を実施する。既存の PCでは得られなかった計算結果や解析規模の拡大などを通じて、 建築諸分野における HPC 環境の適用性について検討を行う。

\section{HPC 環境の構築}

Intel 社製の 4 コア CPU を搭載し、64bit メモリをそれぞれ 4GB ずつ搭載したコンピュータ（Dell 社製の市販の AT 互換機）を 1 ク ラスタノードとする。これを 16 台用意し、1Gbps の有線ネットワー クで連結してコンピュータ・クラスタを用意した。PC は特注仕様 のものではなく、ごく一般的に販売されているものである。

OS は Microsoft 社の「Windows Server 2008 Enterprise Edition」を

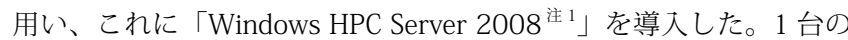
ヘッドノードに対して、15 台のコンピュータをクラスタリングし、 全 16 台とした。そのため、見かけ上 $4 \times 16=64$ コアのCPUを搭載し、 $4 \times 16=64$ GBytes のメモリを搭載した HPC 環境として認識される。 ただし、計画・環境分野に関する研究では 8 台による構成とした。

並列処理のためのメッセージ・パッシング・ライブラリには、 無料で公開されている「MPI.net」注2 を用いた。分析においてこ れを用いる場合は、分析プログラムの開発環境（Microsoft Visual Studio.Net 2008 など）で MPI ライブラリを参照し、並列計算させ る処理を CPU に対して配分するコードを記述するだけである。な お、これらの設備は東京都調布市にある Microsoft 社の Innovation Centerのものを借用した（図 1)。

\section{4. 計画分野：都市の街区構造解析}

\section{1 研究背景}

人間の歩行行動を観察することからモデルを作成し、その演繹的

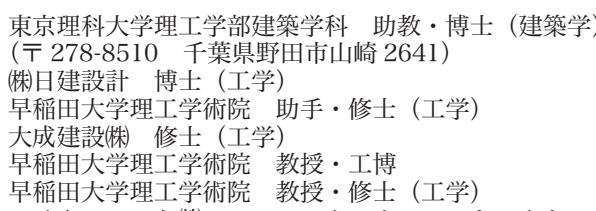

\footnotetext{
Assist. Prof., Dept. of Arch., Faculty of Science and Technology, Tokyo Univ. of Science, Dr. Arch.

Nikken Sekkei Ltd., Dr. Eng.

Research Assoc. Faculty of Sci. and Eng., Waseda Univ., M. Eng.

Taisei Corp., M. Eng.

Prof., Faculty of Science and Engeneering, Waseda Univ., Dr. Eng.

Prof., Faculty of Science and Engeneering, Waseda Univ., M. Eng.

Senior Technical Architect, Microsoft Corp.
} 


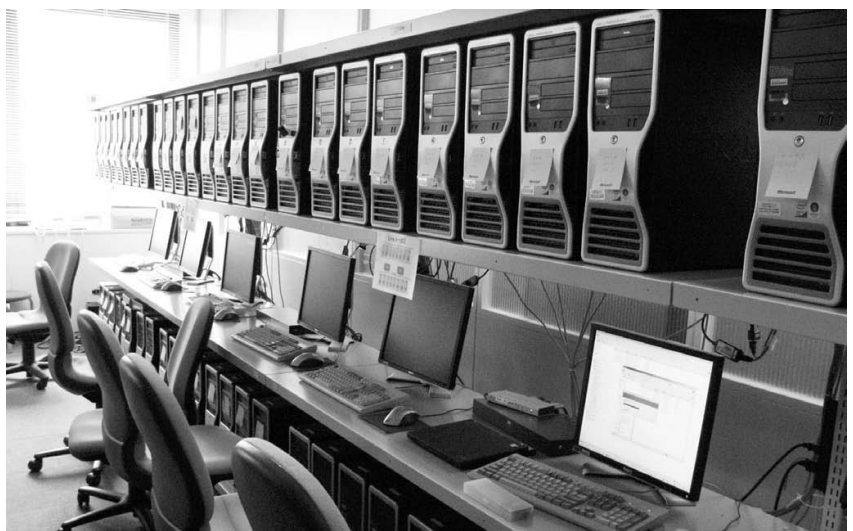

図 1 HPC クラスタ環境

な利用によって歩行行動や避難行動をシミュレーションする研究が 計画分野において実施されてきた。歩行行動をシミュレーションす ることで、駅や商業施設、都市空間などの大規模な公共空間での群 衆の行動を予測し、空間の計画変更による混雑緩和を目指したり、 あるいは、避難行動をモデル化することで、避難時間の予測を行う などといった研究がこれまでに行われている ${ }^{1)}$

近年では、都市の再開発において「まち歩き」の重要性が指摘さ れている。これは消費者マーケティングの流れの中で、商業施設に おける滞留時間が消費者の消費行動と相関があることが知られるよ うになった ${ }^{2)}$ が、その結果を都市に扔ける散策行動にも敷衍でき るという考え方によるものである。実際に、筆者らが都市再開発に 関わる中で、都市空間への滞留者をいかに確保するかというための 議論が長く交わされ、そのための様々な都市機能を充実させるべき であるという意見を提出している注3。

以上のような背景を踏まえ、筆者らは都市の散策歩行に関する研 究を行ってきた。特に、都市の街路構成と歩行者の自由な散策行動 における経路選択との結果から、街路構成における特徴的な箇所を 発見することで、歩行者の都市滞留時間の延長にとって有効な空間 づくり（情報掲示板や休䡯施設、広場などの設置）をおこなうこと を目指している。しかしながら、検証する都市空間を大規模にする ほど計算回数は指数関数的に増大するため、市販の PC 規模の性能 では、事実上、計算結果が得られないということがわかっている。

そこで本報では、HPC 環境を利用し、計算時間の短縮と解析規 模の拡大について検討を行う。

\section{2 研究方法}

複数のノード（交差点・結節点）からなる街区において、その中 からある特徴的なノードを 1 つ以上抽出しようと考えたとき、こ こでは以下のような条件を満たすような場合を考えた。

イ）歩行者は、街区の中の任意のノードから出発する。

ロ）歩行者は、ノードを通過する際、直進、左折、右折のいずれ かの方向転換を選択する。

ハ）歩行者は、事前に設定された回数だけノードで方向転換を行 い、回数の上限に達したとき、歩行を終了する。

二）歩行を終了するまでに、特徴的なノードのうち 1 つ以上を 必ず通過すること。

ホ）以上の条件を満たす時、起点となったノードの総数が、街区 の全ノード数に対して一定の割合を占めること。
このような条件を満たすように抽出されたノードを、ここでは 「OASIS（Operative ASsistant In Strolling：散策歩行支援）ノード」 と呼ぶこととし、また、街区から OASIS ノードを判別するプログ ラムを「OASIS 判別プログラム」と呼ぶこととした。並列化した場 合の処理ルーチンを図 2 に記す。

解析対象とした街区は以下の通りである。一般的に考えられる街 区は、車道と歩道が区別されたものか、あるいは車道と歩道が一体 になっているものが考えられるが、ここでは簡単のため、交差点を 1つのノードとして、ノードとノードの連結（リンク）を歩行の対 象となる街路と見なすこととした。

1) 9 ノードの街区 $(3 \times 3)$

2) 25 ノードの街区 $(5 \times 5)$

3) 100 ノードの街区 $(10 \times 10)$

都市街区ネットワークの概形を図 3 に記す。分析では、これら の街区構成を解析プログラムに読み込ませ、分析処理を実行した。

なお、処理の分散に際し、プロセス 1 は歩行パターン生成、 OASIS ノードの選定組み合わせ生成、他プロセスへの処理の配分と 処理結果の受け取りを受け持たせ、プロセス $2 \sim 32$ は配分された 計算処理のみ行わせた。

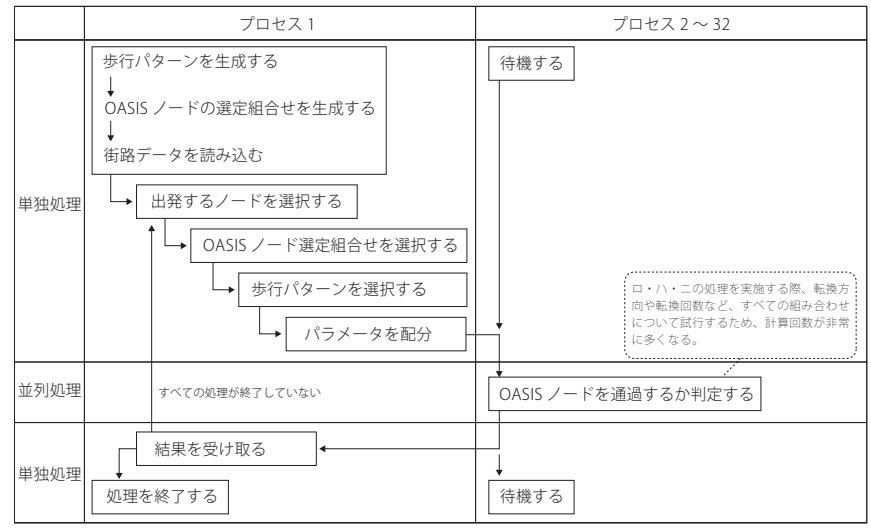

図 2 OASIS ノードの通過判定ルーチンと処理の分散

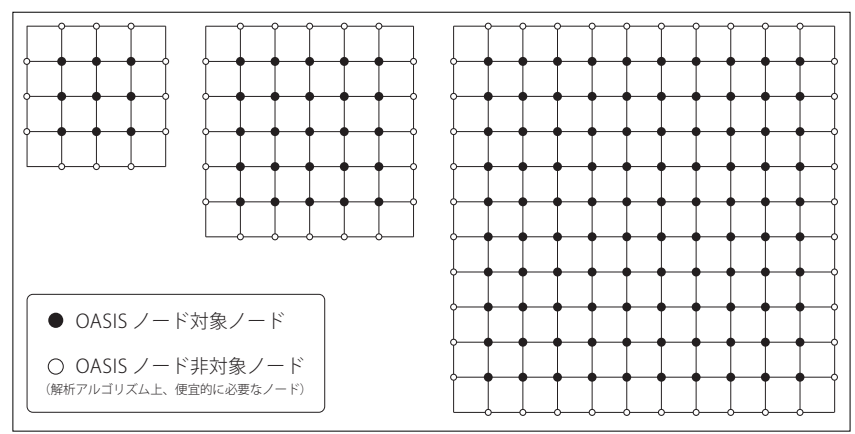

図 3 解析対象とした街区 (左: $3 \times 3$ 、中 : $5 \times 5$ 、右：10×10)

\section{3 結果・考察}

ここでは処理速度の高速化と、解析規模の大規模化についての検 証を行う。検証に用いた OASIS 判別プログラムは、(1)既往研究に おいて解析に用いたプログラム (Perl)、(2) C \# に移植して MPI.net により並列化をする前のプログラム、(3) MPI.net を用いて(2)に並列 化を実装したプログラム（ただし、並列処理の都合上、(2)のコード に対して一部の処理を関数化し、コードの効率化を図った箇所があ る）以上の 3 点である。 


\subsection{1 高速化に関する検証}

解析条件を以下の通りに設定した。

・解析街区は 9 ノードの都市街区とした。

・方向転換回数の上限を $1 \sim 3$ 回の幅で実施した。

• OASIS ノード数を 1〜 5 ノードの幅で実施した。

・条件を満たすような起点ノード数の全ノード数に占める割合

を、50〜100\%の範囲を 10\%刻みで 6 段階に設定した。

ここでの比較結果を図 4 に記す。図 4 より、(1)の条件では 341 秒かかっていた計算が、(2)で258.69 秒、(3)では 3.97 秒で計算が 終了した。(2)では際だった速度向上は見られなかったが、HPC 環 境で並列処理を行った (3)はわめて高速に処理を終了した。HPC 環境を利用することによって大幅な処理速度の改善が期待できるこ とが明らかになった。

\subsection{2 大規模化に関する検証}

解析条件を以下の通りに設定した。

・解析街区は 25 ノードの都市街区とした。

・方向転換回数の上限を $1 \sim 3$ 回の幅で実施した。

• OASIS ノード数を 1〜 5 ノードの幅で実施した。

・条件を満たすような起点ノード数の全ノード数に占める割合

を、50〜 100\%の範囲を 10\%刻みで 6 段階に設定した。

ここでの比較結果を図 5 に記す。図 5 より、(1)の条件では解析 を終了する前にエラーで終了してしまい、解析不能であったが、(2) の条件では 45,450 秒 (約 13 時間)、(3)ではさらに短縮されて 2,146 秒（約 36 分）で終了した。(2)の13 時間という結果は、一般的に 大規模な計算処理の分野では特に大きな数值ではないが、25ノー ドという規模を考えると、大きいと言わざるを得ない。(3)の 36 分 という結果は、(1)で処理が終了しなかったことを考えれば、好まし い結果であったといえる。

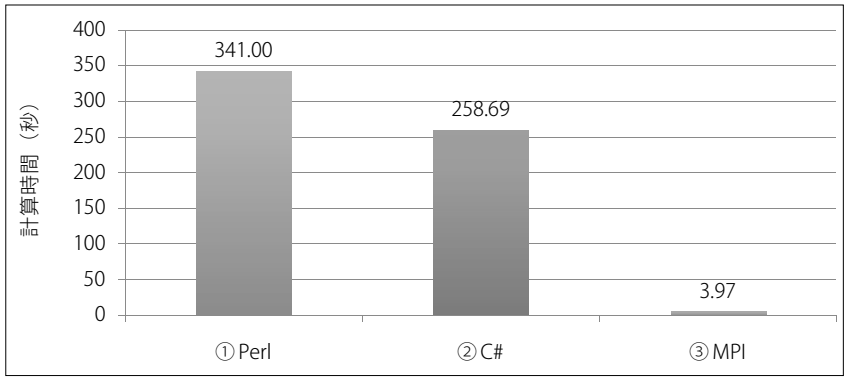

図 4 高速化に関する検証結果

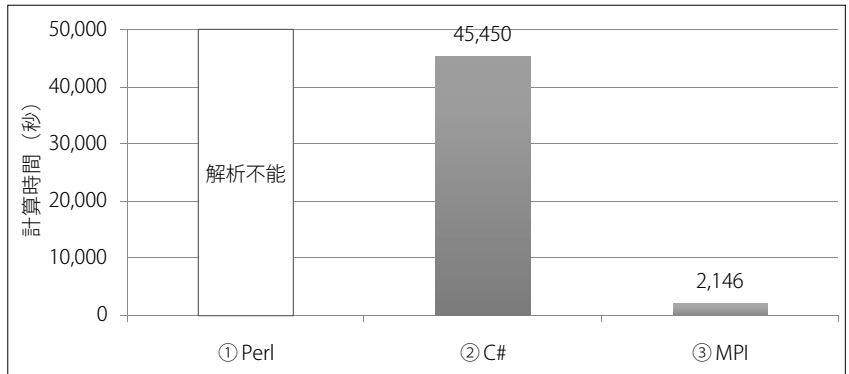

図 5 大規模化に関する検証結果

\section{4 解析結果に関する考察}

以上より、HPC 環境を用いて MPIによる並列分散処理を行うこ とが、処理速度の向上と解析規模の拡大に大きな貢献をもたらすこ
とが明らかになった。ただし、100ノードの街区で解析を実施した ところ、18 時間を経過しても処理が終了しなかったことから、よ り効率的な解析アルゴリズムを構築する必要があると考えられた。

\section{5. 環境分野：建築設備システムのライフサイクル動的シミュレー ション}

\section{1 研究背景}

建物のライフサイクルコストおよびライフサイクル $\mathrm{CO}_{2}$ の過半 は、その運用時に生じることが知られており、運用時における設備 システムの最適化が求められている。一方で、実運用下にある設備 システムが既に一応の安定を示している場合には、さらなる省エネ ルギー化を図るために敢えて制御值の変更を含む各種検討を実施す ることは困難である。このような場面では、建物と設備システムの 挙動を模擬するシミュレーションモデルを用いて、各種の理論的な 検討を予め行うことが有効である。

現在、建築設備分野で実際に利用されているシミュレーションの 多くは、1 時間程度のタイムステップで計算を行い、設備機器の動 的な挙動を考慮しない静的シミュレーションである。このような静 的シミュレーションは制御機器の不良に基づく室温の暴れや、居住 者によるランダムな空調操作などの影響を計算することはできず、 理想的な制御によって室温が室温設定值に合致するという仮定を置 いている。一方、現実には、上述の制御不良や人間行動のランダム 性が室内の快適性や設備のエネルギー消費量に大きな影響を与えて いるという指摘は多い。

この点を定量的に評価するために、「HVACSIM(+)J」や「TRNSYS」 等に代表されるダイナミック（動的）シミュレータが提案されてい る。動的シミュレータは、設備システムを構成する要素を微分方程 式で表現し、これらが相互に連結された設備システムを解くこと で、システムが示す分秒単位の挙動を把握しょうとするものであ る。設備機器の時間遅れを表現することが可能であるため、制御系 の不良についても検討することが可能となる。

動的シミュレーションは、計算精度は高いものの、分秒単位で 初期值問題を解く必要があるため、1 時間タイムステップの静的シ ミュレーションに比較して計算時間が非常に長いという問題があ る。従って、従来、建築 1 棟の年間の計算が動的シミュレーショ ンの対象となることはなく、1ゾーン、ないし 1 フロアを 1 週間程 度計算することがせいぜいであった。一方で、先に記した制御不良 などが建築のエネルギー消費量、室内快適性に与える影響を定量的 に評価するためには、ある程度の規模と期間を持った計算を実行す る必要がある。

この問題を解決するため、本研究では MPIを利用して計算処理 を並列化し、長期大規模な動的シミュレーションの計算可能性を検 討する。

\section{2 研究方法}

建築設備システムは様々な設備機器から構成される複合的なシス テムであるが、必ずしも全ての要素が他の要素に深く影響を与える ものではない。この点を考慮し、例えば動的シミュレータである

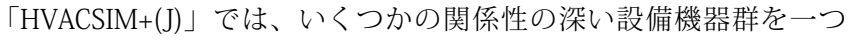
のグループにまとめ、グループ相互の情報伝達は一定時間間隔で行 うという工夫が行われている。また、筆者は 2006 年頃から同様の 
構造による動的シミュレータの開発に取り組んでおり、グルーピン グによる計算速度の向上について報告している ${ }^{3)}$ 。

本研究では、これらのグループのそれぞれに別個の CPUを割り 当て、MPIを利用して一定時間間隔で状態変数を受け渡すことで、 計算速度を向上させた。図 6 に設備機器のグルーピングと状態変 数值伝達の概念を示す。

一般的なオフィスビルを想定し、モデル化を行った。延床面積は $35,700 \mathrm{~m}^{2} 、 21$ 階で各階の床面積は $1,700 \mathrm{~m}^{2}$ とした。両端コアの構 成とし、ペリメータ部分には $3.2 \mathrm{~m}$ 間隔で Fan Coil Unit（FCU）を 配置した。また、モジュールに沿って Air Handling Unit（AHU）の 吹出口を設置した。図 7 に基準階平面図と FCU、AHU 吹出口の配置、 FCU まわりの概念図、冷温水配管を示す。室温を温度センサによっ て感知し、この值と室温設定值との乘離に基づいて冷温水弁に操作 量が決定される。冷温水弁が開閉すると配管を通過する水量に従つ て、冷温水コイルによって除去される熱量が変化し、結果として室 温が変動する。配管の輸送遅れ、温度センサや FCU の熱容量を考 慮しながら微分方程式を解く必要があるシステムである。

FCU 水量を調整する二方弁が設置された冷温水配管は、FCU ご とに独立しているものではなく、他の FCU とも接続されている。 東西各々 14 の FCU が接続されており、特定の FCU の二方弁制御は、 他の FCU の水量に影響を与えることがわかる。このような配管の 水量は図 8 に示すように $14 \times$ 東西 $=28$ 個の節点を持つ回路網を 解くことによって計算できる。また、この回路網が 21 階の東西そ れぞれで存在する。本報では、まずフロア別に回路網を解いてフロ アの合成抵抗を算出することで、全体の回路網を解く方法をとっ た。

以上に示した設備システムモデルを MPIによって並列計算化し た。表 1 にプロセスと計算内容の対応を示す。各フロアの計算を 1 単位とし、60 秒ごとに状態変数值を受け渡す仕様とした。また、 プロセス 1 および 2 は、境界条件の読み込み書き出し処理や設備 システムの制御などの計算を担当させた。

\section{3 並列化の効果}

図 9 に、代表日におけるペリメータゾーンの室温変動および室 温分布を制御パラメータ別に示す。制御パラメータは冷温水二方弁 を操作するための PID 制御器の P (比例制御) 值および I（積分制 御）值である。制御パラメータの設定值に応じて室温の変動の傾向 が異なっていることが確認でき、P 值抢よびI 值の設定值次第で非 常に傾向がことなることがわかる。室温＝室温設定值を仮定する一 般的なシミュレーションでは、このような制御值の不良を評価する ことはできなかった。また、従来の動的シミュレーションではこの ような検討は特定の狭いゾーンに限られていたが、本研究では建物 1 棟すべてについて計算が実行されており、マクロな評価への展開 も可能である。

計算実行中のプロセスの稼働状況を図 10 に示す。左が空調時間 帯、右が非空調時間帯の計算である。状態変数の伝達操作やビル管 理システムの計算を行うプロセス 1 およびプロセス 2 以外につい ては均等に計算が分配され、高い負荷率で計算が行われたことが確 認された。空調時間帯は非空調時間帯に比較して設備側の計算が増 える分、計算処理が重たくなる。このため、状態変数をMPI で受 け渡すコストに比較して計算負荷が十分に大きいため、100\%に近

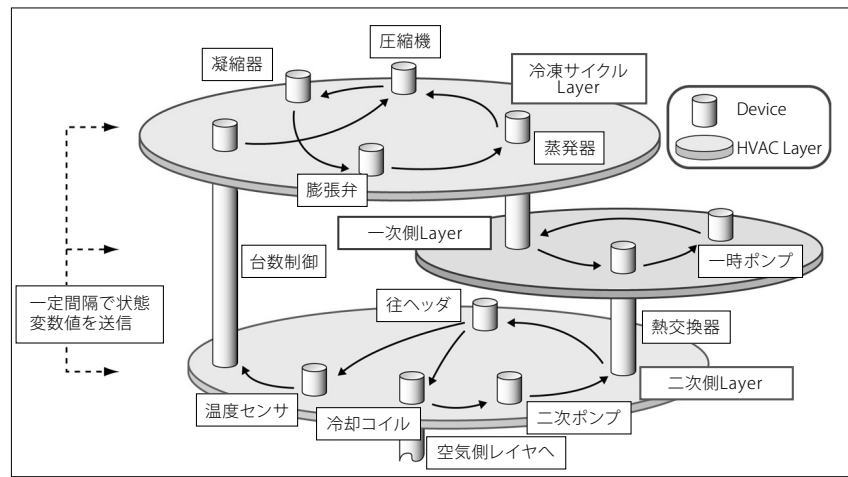

図 6 設備機器のグルーピングと状態変数值伝達の概念

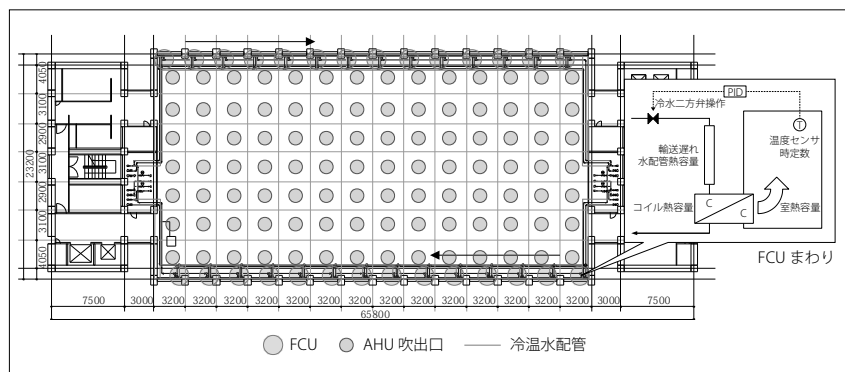

図 7 FCU、 AHU 吹出口の配置・FCU まわりの概念図・冷温水配管

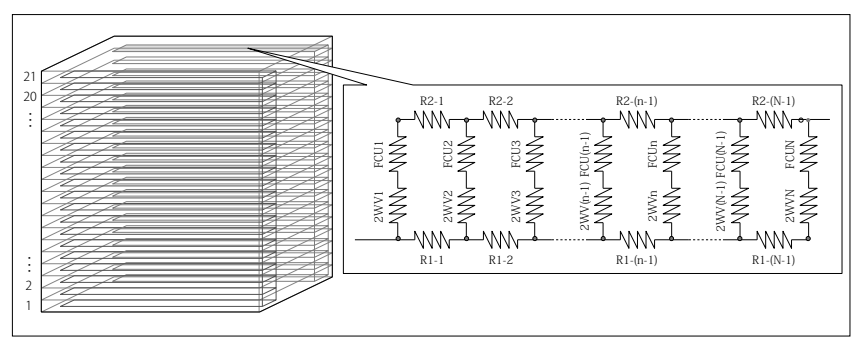

図 8 冷温水配管回路網（各系統と全フロア）

表 1 プロセスと計算内容の対応

\begin{tabular}{|c|c|}
\hline プロセスNo. & 計算内容 \\
\hline 1 & $\begin{array}{l}\text { 境界条件読み込み・補間処理 } \\
\text { プロセスへの状態変数通知と回収 } \\
\text { 状態变数書き出し処理 }\end{array}$ \\
\hline 2 & $\begin{array}{l}\text { 設備システム制御 } \\
\text { 冷温水切り替え } \\
\text { 運転時間帯管理など }\end{array}$ \\
\hline $3 \sim 23$ & 1F〜21Fの計算 \\
\hline
\end{tabular}

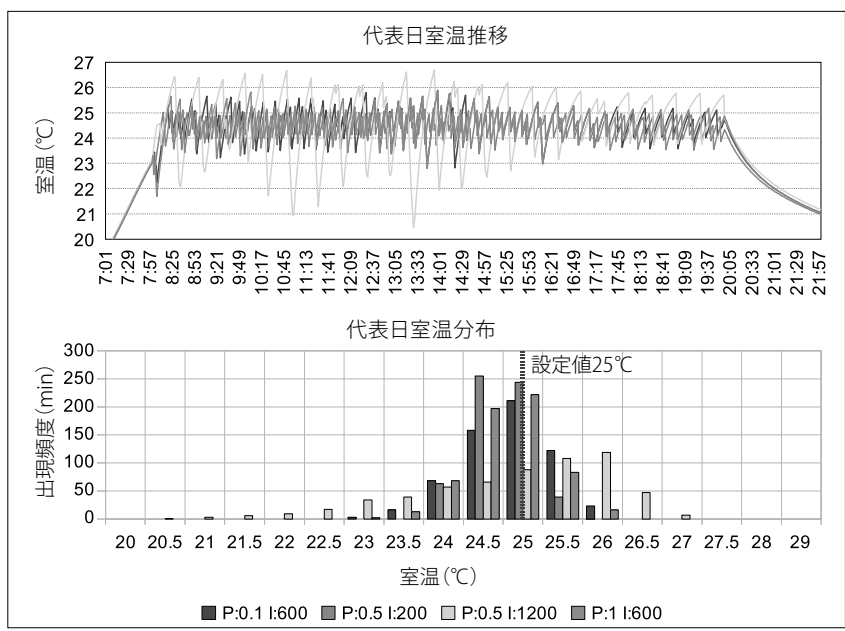

図 9 ペリメータゾーンの室温変動および室温分布

(代表日・制御パラメータ別) 


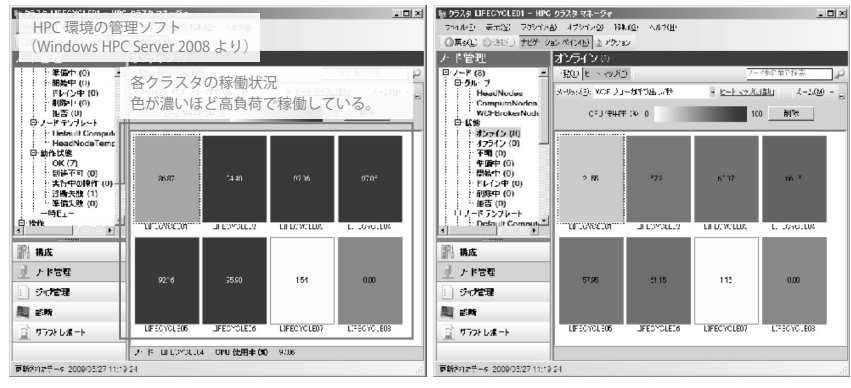

図 10 並列計算中の CPU 稼動状況

(左：空調時間帯 右：非空調時間帯 濃色ほど高稼働率)

い負荷率で計算が行われた。一方、非空調時間帯は状態変数の受け 渡しの処理が相対的に大きくなったため、やや低い負荷率で計算が 行われた。さらに計算速度を向上させるためには、フロアを基準と した単純な計算単位の分割を行うのではなく、負荷に応じた処理の 分割を行う必要があることが示唆された。

一日の計算を行うために、1CPU では 1,034 秒必要であったこと に対し、23CPU では 64 秒で計算が完了し、16.2 倍のスピードアッ プが実現した。設備システムの平均的な耐久年数を 15 年とすると、 $15 \times 365=5,475$ 日の計算が必要であるが、 1 日あたり 64 秒で計算 が可能であるとすれば、 $5475 \times 64 \div 86400=4$ 日で計算が完了 する。現実的な時間内で建築一棟分の設備システムのライフサイク ルにわたる動的計算が実行できる可能性が示されたと言える。

\section{6. 構造分野：不連続変形法を用いた塔体挙動評価 \\ 6.1 研究背景}

有限要素法における並列処理による大規模構造解析を実現する

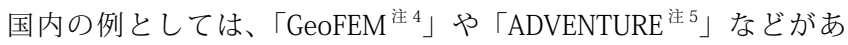
る。高度情報科学技術研究機構により開発されたGeoFEM は、固 体地球分野を対象とした並列有限要素法解析システムである。ソル バは、静的弾性、動的弾性応答、接触、熱伝導、非圧縮性熱流動解 析機能を含んで扔り、メッセージ・パッシング・ライブラリには MPI を用いている。次に、設計用大規模計算力学システム開発プロ ジェクトにより開発された ADVENTURE は、1 億自由度規模の大規 模解析を対象とした、並列計算機上で動作する有限要素法解析ソフ トウェアである。こちらもメッセージ・パッシング・ライブラリに MPI を用いており、専用並列計算機から PC クラスタ型汎用並列計 算機など、多くのコンピュータへの実装が行われている。上記のよ うな大規模なプロジェクト研究があげられる一方、我々が一般的に 使用する汎用構造解析ソフトウェアの ANSYS ${ }^{\text {主 }}{ }^{6}$ や MIDAS ${ }^{\text {主 } 7}$ など においても、計算を並列化する機能は一般的となりつつある。

本節では、離散体力学手法の一つである不連続変形法（以降、 DDA）を組積造建造物に適用する際に、問題となる計算時間の低減 を目的に、DDA にHPC による並列処理を組み込み、検証を行った。 DDA のような離散体力学手法においては、接触判定及びそれによ る係数マトリクスの作成部に多大な計算コストがかかる。この点に おいて、DDA に扔ける並列処理による効果性は高いと考えられる。

本節に抢ける計算アルゴリズムの開発及び並列処理の実装に は、インタプリタ形式のテクニカルコンピュータ言語を利用した $\left\lceil M^{2}\right.$ atlab 注8」(Mathworks 社) を用いている。Matlab は、2007 年
度版より並列処理に対応した Parallel Computing Toolbox などが実 装され、並列処理に関する高度な専門的な知識がなくても並列処理 を組込むことが、以前よりも容易となったという背景がある。

カンボジア、アンコール遺跡の組積造建造物について、著者らは、 日本国政府アンコール遺跡救済チーム（JASA）に扔ける研究の一 部として、構造工学の観点からこれまで調査、研究を行ってきた。 本研究においては、アンコール遺跡建造物の構造安定性評価への 応用を目的とし、DDA に並列処理を組み込んだ際の検証を行うも のである。本研究では、プラサートスープラ N 1 塔 $^{4)}$ をモデルとし て、DDA に扔ける並列処理の組み込みによる計算時間の比較、及 び塔体の変形量、応力状態について検証を行った。プラサートスー プラN1 塔は、図 11 に示すように Platform、1st Story、2nd Story、 3rd Story、Roof の構成からなり、高さは約 $20 \mathrm{~m}$ で、ラテライトブ ロックと一部砂岩ブロックを用いた空積みの組積造建造物である。 プラサートスープラN1 塔のモデル化については、実際の組積法を 完全に反映することは適わず、簡略化してあるが、塔体の変状およ び組積法についての調査結果より妥当であると考えられる図 11 に 示すモデルを作成した。また、基壇下に表層地盤の砂質土（乾燥状 態）をモデル化したバネを配置した。解析に用いた材料特性、DDA の解析パラメータを表 2 に示す。

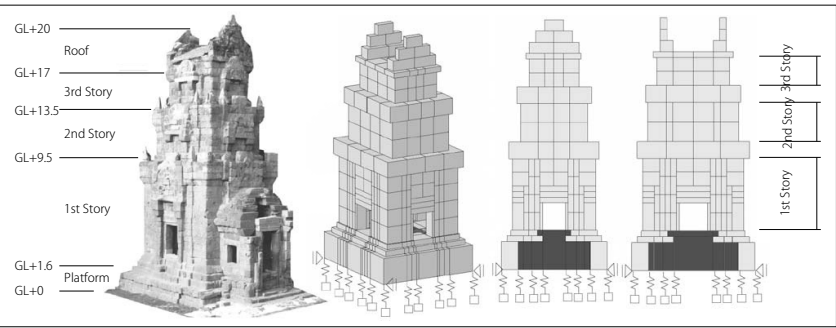

図 11 プラサートスープラ N1 棟外観と DDA 解析モデル

(淡色：ラテライト、濃色：版築土)

表 2 材料特性および解析パラメータ

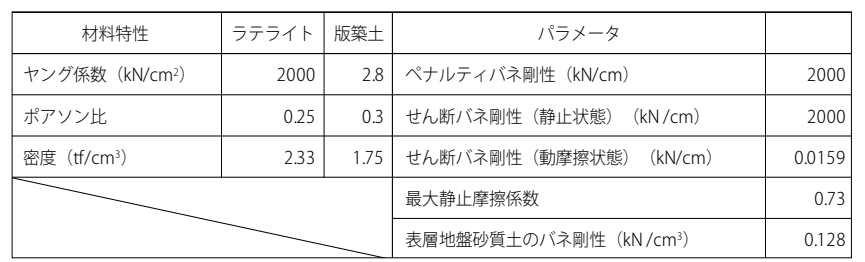

\subsection{DDA の理論と接触判定の方法}

DDA は、G.H.Shi ${ }^{5)}$ により開発された離散体力学手法の 1 つである。 DDA を空積みの組積造に適用する研究には、前田 ${ }^{6}$ らの研究がある。 DDA では、非線形の釣合い方程式にブロック間の貫入によるポテ ンシャルエネルギーを最小二乗法で評価する制約条件を設け、これ を最小にするようにペナルティ法を導入したことに特徴を持ち、要 素間の接触問題抢よび大変形問題を解くことに適した手法であると 言える。DDA における 3 次元の接触状態には、角一面接触、角一 辺接触、辺一辺接触、辺一面接触、面一面接触の 6 種類で表される。 以上の 6 種類の接触状態は全て、角一面接触および辺一辺接触の 2 種類に分類し、それぞれの接触距離判定を行う手法が $\mathrm{Wu}^{7}$ )らによ り示されている。本研究でもWuらが提案した接触判定の手法を採 用している。 


\subsection{DDA への並列処理の組み込みについて}

DDA では、要素数が増加するに従い、接触判定を行う箇所が級 数的に増えるという特徴があり、時刻歴解析および各ステップでの 収束計算を行うには膨大な計算量が必要となる。ただし、バケット サーチ法のようにあらかじめ接触判定を行う箇所を限定する手法に より計算料は節減できる。本研究においても接触判定を行う箇所は 近傍にある要素のみと限定しているものの、計算時間を多く必要と するのは、接触判定および接触マトリクス作成を各接触箇所で行う 部分であり、本研究では、その部分に扔いて並列処理を組み込むこ ととした。ある計算ステップ数における 1 〜 16 CPU での並列処理 による計算速度の比較を図 12 に示す。並列処理を導入したサブマ トリクスの計算ルーチン、及び接触判定の計算ルーチンにおいて は、並列処理による計算時間の短縮が明白にみられる。本研究にお いては、連立方程式の計算ルーチンにおいては、計算モデルの規模 と通信速度の関係性の影響からか並列処理による計算時間の大幅な 増幅が起こったため、連立方程式の計算ルーチンにおいては、並列 処理を用いないという方法を取った。このことについては、今後の 課題として適切な解法を選択する必要があると考えられる。

\section{4 解析結果についての考察}

DDA による解析結果から、FEM による連続体解析とは異なる図 13 のように開口部柱への応力集中など組積法により発生すると考 えられる応力分布が確認できる。また、図 11 に示すように設定さ れた 1st Story、2nd Story、3rd Storyにてそれぞれの変位成分の最 大值について、塔体及び基壇全てを連続体とした FEM で得られた 変位と、本節で得られた解析結果とを比較した（表 3)。FEMに比 較して、DDA の方が各変位成分を大きく評価していることが分か る。アンコール遺跡のような空積みの組積造建造物においては、連 続体解析では応力、変形量を適切に評価することは困難であると考

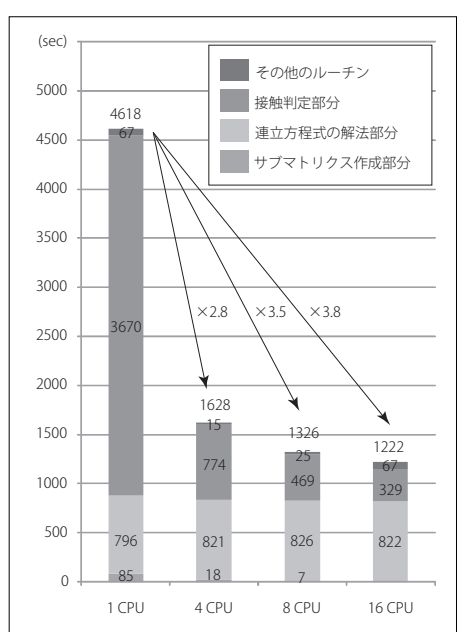

図 12 計算時間の比較

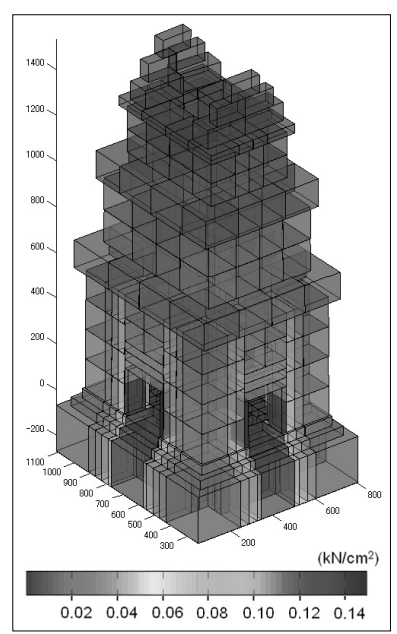

図 13 鉛直方向軸応力度図
表 3 各变位成分における DDA と FEM の值の比較

\begin{tabular}{|c|c|c|c|c|}
\hline & & DDA & FEM & DDA/FEM \\
\hline \multirow{3}{*}{ 1st Story } & $\mathrm{Uz}(\mathrm{cm})$ & 0.938 & 0.046 & 20.20 \\
\hline & $\mathrm{Ux}(\mathrm{cm})$ & 0.775 & 0.024 & 32.70 \\
\hline & Uy $(\mathrm{cm})$ & 0.786 & 0.046 & 16.90 \\
\hline \multirow{3}{*}{ 2nd Story } & $\mathrm{Uz}(\mathrm{cm})$ & 1.580 & 0.269 & 5.90 \\
\hline & $\mathrm{Ux}(\mathrm{cm})$ & 0.663 & 0.005 & 131.50 \\
\hline & Uy $(\mathrm{cm})$ & 1.090 & 0.046 & 23.90 \\
\hline \multirow{3}{*}{ 3rd Story } & $\mathrm{Uz}(\mathrm{cm})$ & 2.040 & 0.292 & 7.00 \\
\hline & $\mathrm{Ux}(\mathrm{cm})$ & 0.933 & 0.003 & 277.70 \\
\hline & Uy $(\mathrm{cm})$ & 1.950 & 0.052 & 37.80 \\
\hline
\end{tabular}

えられ、本研究におけるDDA のような離散体力学手法による応力、 変形量評価の手法を今後も進めていく必要がある。

\section{7. まとめ}

計画・構造・環境の三分野それぞれの研究において、HPC 環境 を用いた大規模な並列演算処理を実施し、これまでの計算機環境下 では得られなかった計算結果や、解析規模の拡大などを通じ、建築 諸分野における HPC 環境の利用可能性について明らかにした。

特に、本研究で用いた HPC 環境は、既存の PC をクラスタリン グすることを想定した機材構成になっており、導入に際してハード ウェアコストを低く抑えることが可能であり、また、MPI を実装す る際のプログラムに関する手法も、オープンなライブラリを導入す るだけで済み非常に扱いやすく、並列計算を専門としない者であっ ても容易に並列演算処理を実施することができた。

以上より、安価に構成された HPC 環境とMPIによる並列演算処 理は、建築分野全般において、大規模な計算を要する解析処理など の場面で有効な手段になり得るものと考えられる。

\section{参考文献}

1) 木村謙, 佐野友紀, 林田和人, 竹市尚広, 峯岸良和, 吉田克之, 渡辺仁 史：マルチエージェントモデルによる群集歩行性状の表現 歩行者シミュ レーションシステムSimTread の構築, 日本建築学会 計画系論文集, No.74 (636), pp.371-377, 2009.2

2) 降旗徹馬, 西野和美, 寺崎康博: 顧客の店舗内滞留時間と購買額の関 連性に関するモデル分析, 日本経営工学会 春季大会予稿集, No.2003, pp.34-35, 2003.5

3）小川崇臣, 田中太一, 富樫英介, 田辺新一：建築設備シミュレーション における知価共有フレームワーク『Popolo』の開発（第３報）NLEs お よびIDEsソルバの実装とレイヤー構造によるシステムの解法, 空気調 和・衛生工学大会 論文集, pp.1199-1202, 2007.8

4) Takeshi Nakagawa (Supervisor) et al. : Report on the Conservation and Restoration Work of the Prasat Suor Prat Tower. Tokyo: Japanese Government Team for Safeguarding Angkor., 2005

5) 大西有三, 佐々木猛, G.H.Shi, 不連続性岩盤解析実用化研究会：計算力 学レクチャーシリーズ 6 不連続変形法 (DDA), 丸善株式会社, 2005.5

6 ）杉浦良和, 前田寿朗 : 不連続変形法 (DDA) による空積組積造遺跡建築の 解析, 日本建築学会学術講演梗概集 B-1 構造 1, Vol.2005 pp.313-314 2005.7

7 ) WU Jian-Hong, OHNISHI Yuzo, NISHIYAMA Satoshi, SHI Gen-Hua : Theory of Three-Dimensional Discontinuous Deformation Analysis and Its Application to a Slope Toppling at Amatoribashi, Japan, Int J Geomech, Vol.5 No.3, pp.179-195, 2005.9

注

注 1 ) Microsoft HPC Server 2008: http://www.microsoft.com/japan/ hpc/default.mspx（参照 2010-2-18)

注 2) MPI.NET High-Performance C\# Library for Message Passing : http://www.osl.iu.edu/research/mpi.net/ (参照 2010-2-18)

注 3 ）さいたま市：http://www.city.saitama.jp/www/contents/12318991 71148/index.html（参照 2010-2-18)

注 4 ） GeoFEM : http://geofem.tokyo.rist.or.jp/index_.jp.html（参照 20102-18)

注 5 ） ADVENTURE : http://adventure.sys.t.u-tokyo.ac.jp/jp/（参照 20102-18)

注 6) ANSYS : http://www.cybernet.co.jp/ansys/ (参照 2010-2-18)

注 7) MYDAS : http://www4.kke.co.jp/midas/ (参照 2010-2-18)

注 8) Matlab : http://www.mathworks.co.jp/products/matlab/（参照 20 10-2-18)

[2010 年 2 月 18 日原稿受理 2010 年 5 月 10 日採用決定］ 